\title{
Control of Fungal Paper Deterioration by Antifungal Drugs, Essential Oils, Gamma and Laser Irradiation
}

\author{
D.M.I. Ali ${ }^{1}$, T.M. Abdel-Rahman ${ }^{1}$, N.F. El-Badawey ${ }^{2}$ and \\ E.A.M. Ali ${ }^{1}$ \\ ${ }^{1}$ Botany Department, Faculty of Science, Cairo University and \\ ${ }^{2}$ Plant Pathology Research Institute, Agriculture Research \\ Center, Giza, Egypt.
}

\begin{abstract}
7 HIS STUDY aimed to control two selective fungi (Aspergillus parasiticus and Penicillium commune, causing biodeterioration of books and documents in storage areas of libraries) using antifungal drugs, essential oils (added singly and in combination), gamma irradiation and laser radiation. The results obtained indicated that fluconazole and clotrimazole were effective against $A$. parasiticus and $P$. commune, while nystatin was of lesser effect .P. commune showed more resistance than $A$. parasiticus to the antifungals $\left(\mathrm{MIC}_{60}\right.$ determination). Cinnamon and clove oils were efficient antifungal agents, while garlic and thyme oils have no reasonable activities. The combination treatment revealed some synergestic interaction between garlic and thyme oils with antifungal drugs. Generally the highest control of both fungal species was shown by single treatment of clotrimazole. It was found that the two fungi responded differently against $\gamma$ - irradiation. A. parasiticus was more tolerant than $P$ .commune in dry biomass, while they were equal in $\gamma$ - irradiation tolerance in the cfu / plate. The $\mathrm{D}_{10}$ determination revealed more tolerance of $P$. commune than $A$. parasiticus. The two fungal species showed resistance in their growth parameters (cfu and dry biomass) with laser beam treatment for $1-5$ min. Reductions of $75 \%$ to $95 \%$ of control was detected after 10 and 15 min exposure to laser beam. The lethal effect, however, was observed after $20 \mathrm{~min}$ for both fungi.
\end{abstract}

Keywords: Control paper biodeterioration, Aspergillus parasiticus and Penicillium commune, Antifungal drugs, Essential oils, Gamma irradiation, Laser radiation

Biodeterioration of library materials is a worldwide problem due to the vast numbers of libraries spread allover the world and the number of volumes stored in the library buildings (Zyska, 1997). Biodeterioration can be defined as a change in material properties due to the vital activities of the organisms (Hueck, 1965 ) and biofouling is the accumulation of biological deposit on a surface (Beech and Sunner, 2004). Biodeterioration and biofouling are due to microbiological, biological and physicochemical processes (Beech and Sunner, 2004). 
A wide range of materials can be affected and among them are the following: metals, paints, paper, paper-board, rocks, photos, textiles, leather, plastics, etc. These materials, depending on the microclimatic conditions (temperature and relative humidity), can suffer from physical, chemical and esthetic damage caused by insects, algae, lichens, fungi and bacteria (Villalba et al., 2004; Borrego et al., 2010). The purpose of libraries, archives and museums is to preserve the items collected, enabling access to the knowledge contained in books and documents and enjoyment of the artworks contained on paper. Longterm preservation of the collections of historic, artistic and cultural heritage of these repositories involves controlling the environment in which they are kept and exhibited (Reis-Menezes et al., 2011).

The microbial degradation of documents is one of the most serious and unappreciated sources of damage to library and archived materials (Cappitelli and Sorlini, 2005). The presence of spores or vegetative cells of microorganisms on the surface of documents may indicate a possible degradation in the future (Mesquita et al., 2009). Microorganisms, particularly fungi, because of their cellulolytic activity are potential candidates responsible for paper deterioration (Coughian et al., 1993). Microorganisms, because of their rapid reproduction and physiological activity, generally are highly adaptive to environmental conditions. Thus, they can rapidly reproduce on various substrates, causing them to discolour or decompose (Kowalik, 1980). They often cause degradation of objects such as paintings, stone, wood, paper, masonry, leather, parchment, glass, metal, and cinematographic films (Cappitelli and Sorlini, 2005; Abrusci et al., 2005).

The antifungal properties of different compounds designed to control the presence of filamentous fungi on industrial paper or archives have been evaluated (Gilbert and Brown, 1995; Rakotonirainy et al., 1999; Clausen, 2000). Parks and Casey, 1996 reported that there are three major groups of antifungal agents which inhibit synthesis of or direct interact with ergosterol the predominant component of the fungal cell membrane), Azoles (such as miconazole, econazole, ketoconazole, fluconazole and itraconazole), polyenes (such as amphotericin B) and allylamine (such as terbinafine and naftifine).

Azoles are compounds used in dermatology as antifungal drugs (Harvey, 1985) and in plant pathology against fungal diseases. They act by selectively impairing the cytochrome P.450 dependant 14 dे-demethylase, a key enzyme of ergosterol biosynthesis (Vanden- Bossche, 1990). Polyene compounds lead to breakdown of cell wall constituents, so it altered permeability and leakage of vital cytoplasmic components and death of microorganisms. Chemicals that specially inhibit chitin (main component of fungal wall) and ergosterol (main component of fungal membranes) are used to prevent fungal infections and contaminations.

Since antiquity, volatile oils from herbs, spices and plants have been recognised as having biological activities. In recent years, there has been

Egypt. J. Bot., 54, No.2 (2014) 
renewed interest by scientists in the use of these natural substances for their antibacterial and antifungal properties. However, among several studies reported, only a few mention their eventual use in the field of conservation of cultural properties (Chingduang et al., 1995; Dhawan, 1995; Perumal and Wheeler, 1997; Gatenby and Townley, 2003). In Asia, some traditional practices have already been applied in museums and libraries. Several conservators are beginning to use this kind of product in Western countries. Published results on the antifungal activity of essential oils have been mainly concerned with fungi studied in an individual way (Hitokoto et al., 1980; Thompson, 1989; Mahmoud, 1994; Pattnaik et al., 1996; Adams et al., 1996; Bishop and Thornton, 1996; MontesBelmont and Carvajal, 1998; Guynot et al., 2003). However, in the environment fungal populations are often a combination of many species. Many factors affect the constituents of essential oils. Depending on the methods of extraction, ecological factors and biological parameters, the same species of plant can give rise to essential oils with different composition and different type of action (Pellecuer et al., 1976; Arras and Grella, 1992; McGimpey et al., 1994; Echeverrigaray et al., 2003). Conversely, there are sometimes more similarities between actions of oils produced by different species of plants than oils produced by the same species. It is worth noting that essential oils are very expensive. Therefore, it appears more judicious to use a pure component (more stable) than an essential oil itself.

Gamma irradiation as sterilizing treatment causes direct damage to cell DNA through ionization inducing mutation and killing the cell. It also has an indirect effect as a result of radiolysis of cellular water and formation of active oxygen species, free radicals and peroxides causing single and double strand DNA breakages (McNamara et al., 2003).

Gamma rays, electromagnetic waves with high penetrating power, pass through materials without leaving any residue, an advantage comparing to other disinfection treatments, since the handling of books and documents may be done safely just after irradiation (Adamo et al., 1998 and 2001). Studies demonstrated that the damage in mechanical-physical properties caused by gamma rays on paper was not significant (Adamo et al., 1998 and 2001; Gonzalez et al., 2002). These studies were extended to the color of printing inks on paper and the result was that they are resistant to gamma radiation (Rocchetti et al., 2002).

Today radiation process for books and documents preservation is a continuous controversy, but many countries are trying to fix doses and conditions to be suggested and used as a suitable option.

Fungi have been successfully inactivated from different materials, such as paper, wood and soil with radiation doses ranging from 6 to $15 \mathrm{kGy}$ (Hanus, 1985; Jorg et al., 1992; Pointing et al., 1998; McNamara et al., 2003). However, in a Brazilian study some fungi from books could not be completely eliminated after irradiation with doses of $20 \mathrm{kGy}$ (Tomazello and Wiendl, 1995). Thus, 
recent studies on the irradiation dose required to inactivate fungi were conducted on axenic cultures and on naturally contaminated books and documents, taking into account the tropical climatic conditions present in Brazil and its rich fungal diversity, resulting in many different fungal species as potential biodeteriorating agents.

Laser irradiation is used as a successful control to human pathogenic bacteria and fungi (Burns et al., 1993; Smijs and Schuitmaker, 2003; Vural et al., 2007; Manevitch, et al., 2010). Nowadays, portable laser systems can remove contaminants from substrates with no surface damage, thus being a great solution for conservation of documents and art objects (Speranza et al., 2012).

This study aimed to determine whether the traditional antifungal drugs or essential oils could be used to control fungal deterioration of documents in storage areas of libraries. Furthermore, the role of gamma and laser irradiation in fungal control and some enzymes activities were also studied.

\section{Material and Methods}

\section{Selected organisms}

Two fungal species (Aspergillus parasiticus \& Penicillium commune) were previously isolated from fungal deteriorated books located in Cairo University old library and were identified by phenotypic and molecular technique. These two species were used as models to control the paper biodeteriorating fungi as they were the most frequent fungal species in the isolation experiment. They were tested to show how far they will be affected by some antifungal agents, essential oils, gamma and laser irradiation.

\section{Effect of some antifungal drugs on fungal growth}

a. Tested antifungal drugs from local market

b. Concentrations used of antifungal drugs

Serial dilutions of fluconazole were made by ethanol $50 \%$ to obtain the following concentrations: $3.75,7.5,15,30$ and $60 \mathrm{mg} \mathrm{ml}^{-1}$. Nystatin was diluted by sterile distilled water to obtain 25000, 50000 and $100000{\mathrm{I} . \mathrm{Uml}^{-1}}^{1}$ concentrations. Clotrimazole concentrations were diluted to 5 and $10 \mathrm{mg} \mathrm{ml}^{-1}$ by sterile distilled water (Table 1).

TABLE 1. list of tested antifungal drugs .

\begin{tabular}{|c|c|c|c|}
\hline Drug & $\begin{array}{c}\text { Active } \\
\text { component }\end{array}$ & Concentration & Manufactured by \\
\hline Fungican & Fluconazole & $\begin{array}{c}\text { Each capsule } \\
\text { contains } 150 \mathrm{mg}\end{array}$ & $\begin{array}{c}\text { Amoun Pharmaceutical Co., } \\
\text { Cairo, Egypt. }\end{array}$ \\
\hline Nystatin & Nystatin & $100,000 \mathrm{I} . \mathrm{Ul}^{-1}$ & E.I.P.I.Co., Egypt. \\
\hline Dermatin & Clotrimazole & $10 \mathrm{mgml}^{-1}$ & $\begin{array}{c}\text { PHARCO Pharmaceuticals, } \\
\text { Alex, Egypt. }\end{array}$ \\
\hline
\end{tabular}

Egypt. J. Bot., 54, No.2 (2014) 
c-Antifungal susceptibility test using diffusion agar plate method

Spore suspensions of Aspergillus parasiticus and Penicillium commune were prepared. $250 \mu$ of each spore suspension were seeded into $250 \mathrm{ml}$ Malt Extract Peptone Agar (MEPA) medium (Merk, 1982) containing flasks. Media were poured immediately in sterile Petridishes and left to solidify. Wells of $5 \mathrm{~mm}$ diameter were made in the agar plates by sterile cork borers. Each well received $100 \mu 1$ of each antifungal drug. Control plates contained sterile distilled water. Plates were incubated at $27 \pm 2^{\circ} \mathrm{C}$ for 3-5 days.

After the end of the incubation period, the sensitivity of fungi to the tested drugs was determined by measuring the mean diameter of the growth inhibition zones in $\mathrm{mm}$. The relative activity (RA) percent was also calculated. The minimum inhibitory concentration $\left(\mathrm{MIC}_{60}\right)$ was determined (if achieved) as the least concentration of antifungal that inhibit $60 \%$ of fungal growth.

Effect of Essential oils on fungal growth

The activity of the tested essential oils was estimated by using diffusion plate method described above (Table 2).

TABLE 2. List of tested essential oils.

\begin{tabular}{|l|l|l|}
\hline \multicolumn{1}{|c|}{ Essential oil } & \multicolumn{1}{|c|}{ Active component } & \multicolumn{1}{c|}{ Manufactured by } \\
\hline Clove oil & Eugenol & Elcaptaincompany, Cairo, Egypt. \\
\hline Thyme oil & Thymol & Elcaptain company, Cairo, Egypt. \\
\hline Cinnamon oil & Cinnamon aldehyde & Elcaptain company, Cairo, Egypt. \\
\hline Garlic oil & Allicin & Elcaptain company, Cairo, Egypt. \\
\hline
\end{tabular}

Effect of combinations between antifungal drugs and essential oils on fungal growth

Combinations between the highest concentration of antifungal drugs and essential oils had been also tested and the interaction between them was expressed as functional inhibitory concentration index (FICI) (Mukherjee et al., 2005).

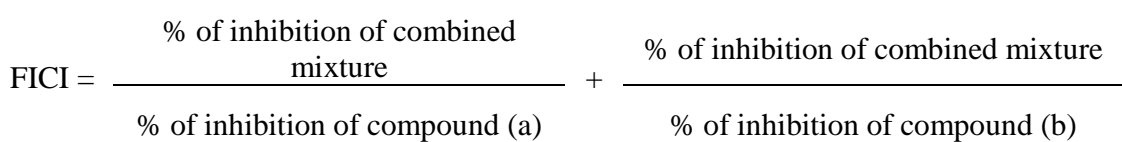

FICI $<0.5$ means antagonism.

$\mathrm{FICI}=0.5-4.0$ means indifference.

FICI $>4.0$ means synergism. 
Effect of gamma radiation on fungal growth

a. Source and doses of gamma radiation

Spore suspensions from 7-day old cultures of each of the two selected fungi (Aspergillus parasiticus and Penicillium commune) were irradiated in a $\mathrm{CO}^{60}$ unit Gamma cell 220 Excel in the National Center for Radiation Research and Technology (NCRRT), Cairo, Egypt, at dose rate $2.48 \mathrm{KGy} / \mathrm{h}$. Spore suspensions were exposed to increasing doses of gamma radiation; $0.0,0.2,0.4,0.6,0.8,1.0$ and $2.0 \mathrm{KGy}$, for studying the effect of irradiation on fungal growth.

b. Determination of decimal reduction dose ( $D_{10}$-value)

Immediately after irradiation, $10^{-1}$ dilution of spore suspensions was made from each dose. Then, $100 \mu \mathrm{l}$ from each dilution were seeded into $100 \mathrm{ml}$ of MEPA medium containing flasks. The media were poured in sterile Petri dishes and left to solidify. Controls were made of spore suspensions not exposed to gamma radiation. Plates were incubated at $27 \pm 2{ }^{\circ} \mathrm{C}$ for $3-5$ days, then the number of colonies was manually counted in each plate.

The radiation sensitivity of two test fungi was expressed in terms of $D_{10}$ values. The $\mathrm{D}_{10}$-valuewas determined by calculating the negative reciprocal of the slope by linear regression after fitting the survival data versus irradiation doses(Choi et al.,2012).The $\mathrm{D}_{10}$-value for each fungus was calculated using the regression line:

$$
\begin{aligned}
& Y=a+b x \\
& D_{10}=-1 / b \\
& B=\sum x y-n x^{\prime} y^{\prime} / \sum x^{2}-n^{\prime 2}
\end{aligned}
$$

\section{Where}

$\mathrm{a}=\log$ of microbial count when $\mathrm{x}$ equal zero.

$\mathrm{b}=$ regression factor.

$\mathrm{x}=$ dose level (KGy).

$\mathrm{y}=$ microbial count (log count).

$\mathrm{n}=$ number of treatments.

$\mathrm{x}^{\prime}=\sum \mathrm{x} / \mathrm{nandy}=\sum \mathrm{y} / \mathrm{n}$

c. Effect of different doses of gamma radiation on the fungal mycelial dry biomasses

For each treatment of both fungi, three conical flasks ( $250 \mathrm{ml}$ volume), each containing $100 \mathrm{ml}$ Czapek-Doxs liquid medium were inoculated, each with $1 \mathrm{ml}$ of the previously irradiated spore suspension. Non-irradiated spore suspensions were used as controls. The flasks were incubated at $27 \pm 2^{\circ} \mathrm{C}$ for 7 days, after which the produced mycelial mats were collected by filteration, oven-dried at $60^{\circ} \mathrm{C}$ (until constant weight) then weighed to determine the final dry biomass as a measure of fungal growth.

Egypt. J. Bot., 54, No.2 (2014) 
d. Effect of different doses of gamma radiation on the fungal proteolytic, cellulolytic and amylolytic activities

Amylase and cellulase activities were determined by measuring the release of reducing sugars from starch and cellulose, respectively using the dinitrosalicylic acid (DNS) method (Ghose, 1987). Proteolytic activity was determined by measuring the release of amino acids using ninhydrin reagent (Jones et al., 2002).

Control of paper deteriorating fungi by laser radiation

Spore suspensions from Aspergillus parasiticus and Penicillium commune were exposed to the green light $(532 \mathrm{~nm})$ continuous wave $(\mathrm{CW})$ from a Diode Pumped Solid State (DPSS) laser [LSR-PS-II] in the National Institute of Laser Enhanced Science (NILES), Cairo University, Egypt. For stability, the laser was turned on $10 \mathrm{~min}$ before starting the irradiation. Spore suspensions of the two fungal species were exposed for different exposure times to laser radiation; 0,1 , $2,3,4,5,10,15$ and 20 minutes. Then, the number of viable colonies and the dry biomass were also determined as described previously in gamma irradiation experiments.

Statistical analyses

The results were expressed as the mean \pm standard deviations (mean $\pm \mathrm{SD}$ ). Data were analyzed by one-way analysis of variance (ANOVAs) using SPSS statistical program, version, 16. The differences among the mean values of some experiments were compared by the Duncan's Multiple Range Test (DMRT) with the significance set at $p \leq 0.05$.Statistical analysis of other experiments was performed using Student's test, where $p$-values $\leq 0.05$ were considered significant.

\section{Results and Discussion}

Effect of some antifungal drugs on the growth of Aspergillus parasiticus and Penicillium commune

In Fig. 1, it was found that $P$. commune was more resistant to the three tested antifungal drugs, fluconazole (a), clotrimazole (c) (Azole group) and nyastatin (b) (polyene group) than A. parasiticus which showed high susceptibility especially against fluconazole. In all cases the sensitivity of the two fungal species was a function of antifungal concentrations. The $\mathrm{MIC}_{60}$ was achieved in the presence of $60.0 \mathrm{mg} \mathrm{ml}^{-1}$ fluconazole and $10.0 \mathrm{mg} \mathrm{ml}^{-1}$ clotrimazole against $A$. parasiticus, while it was not achieved against $P$. commune in any cases.

It is worthy to mention that Fabbri et al. (1997) reported the inhibition of some paper deteriorating fungi by antifungals such as antioxidants (butylated hydroxyl toluene and butylated hydroxyanisole); azole antifungals (econazole, miconazole, ketoconazole) and chitin synthase inhibitors (vridine, 5- fluorouridin-2deoxyuridine) against Penicillium chrysogenum, Aspergillus terreus, Stachybotrys atra and Chaetomiumelatum. The most evident inhibitory effect on fungal growth has been obtained with miconazole and econazole at $10^{-3} \mathrm{M}$ and to lesser extent butylated hydroxytoluene and butylated hydroxyanisole. 


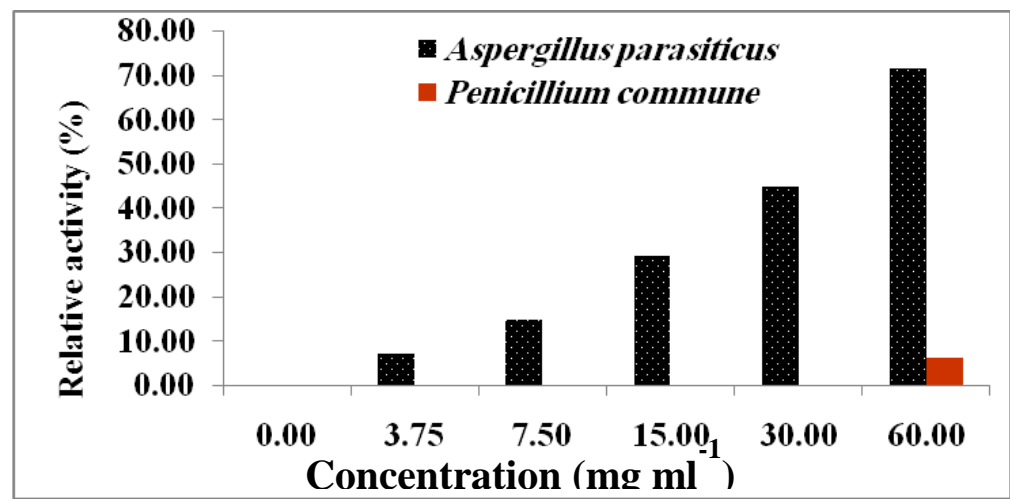

Fig. 1 (a). Effect of different concentrations of fluconazole on the growth of Aspergillus parasiticus and Penicillium commune.

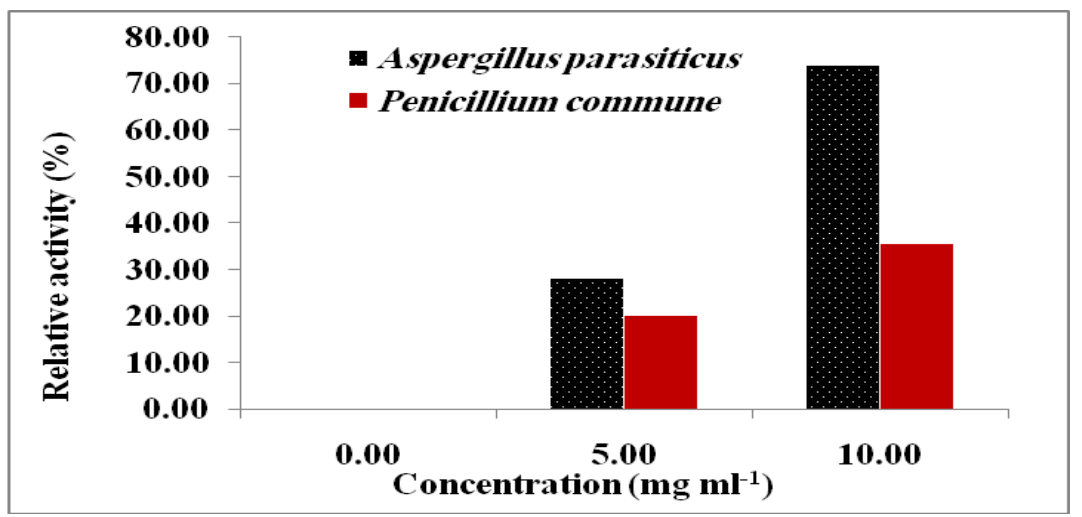

Fig. 1 (b). Effect of different concentrations of nystain on the growth of Aspergillus parasiticus and Penicillium commune.

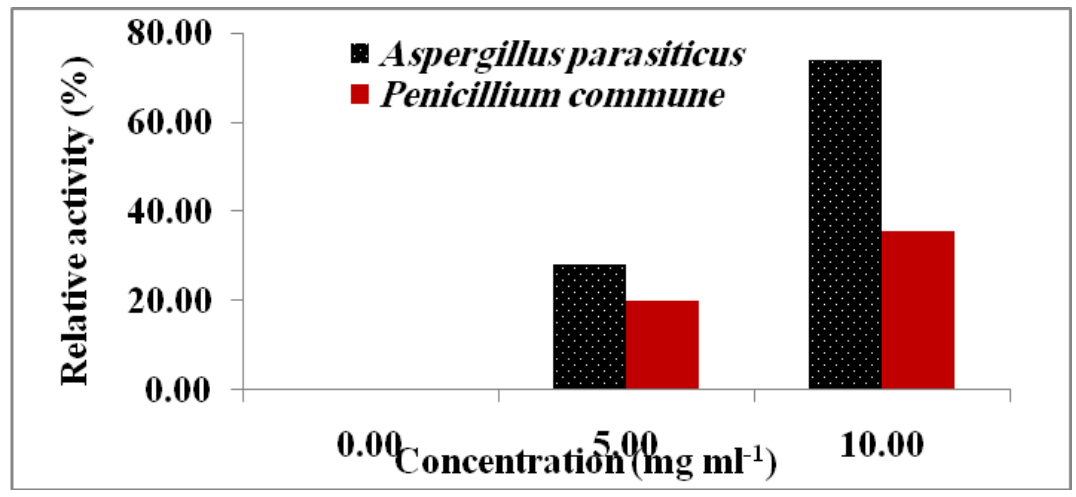

Fig. 1 (c). Effect of different concentrations of clotrimazole on the growth of Aspergillus parasiticus and Penicillium commune.

Egypt. J. Bot., 54, No.2 (2014) 
In this connection Neves et al. (2009) demonstrated that the minimum inhibitory concentration (MIC) of the antifungal methyl and propyleparabens against Cladosporium species and Penicillium corylophilum isolated from paper artistic works was $5 \%$ and $1 \%$, respectively. Calcium propionate $5 \%$ was added to ethanolic mixture of both compounds to produce a multipurpose formulation for deacidification and decontamination of paper documents. This treatment shows only minor increase in fiber strength, while raising the $\mathrm{pH}$ cause alkaline reserve with minimum paper deformation.

The antifungal activity of essential oils against paper fungal deteriorating fungal growth

The bioassay of the antifungal activities of some essential oils (cinnamon, clove, garlic and thyme) indicating that cinnamon and, to lesser extent, clove oils exerted reasonable antifungal activities against the paper deteriorating fungi Aspergillus parasiticus and Penicillium commune. Garlic and thyme oils, however, had no detectable antifungal activities against both fungal species (Table, 3).

TABLE 3. The antifungal activity of essential oils against Aspergillus parasiticus and Penicillium commune growth.

\begin{tabular}{|c|c|c|c|c|}
\hline \multirow[b]{2}{*}{ Treatment } & \multicolumn{2}{|c|}{ Aspergillus parasiticus } & \multicolumn{2}{|c|}{ Penicillium commune } \\
\hline & $\begin{array}{l}\text { Inhibition zone } \\
\text { diameter (mm) } \\
\text { (Mean } \pm \text { SD) } \\
\text { SD) }\end{array}$ & $\begin{array}{l}\text { Relative } \\
\text { activity } \\
(\%) \\
\text { (Mean } \pm\end{array}$ & $\begin{array}{l}\text { Inhibition zone } \\
\text { activity } \\
\text { diameter }(\mathbf{m m}) \\
(\text { Mean } \pm \text { SD) }\end{array}$ & $\begin{array}{c}\text { Relative } \\
(\%) \\
(\text { Mean } \pm \text { SD }\end{array}$ \\
\hline Control & $0.00 \pm 0.00^{\mathrm{a}}$ & $0.00 \pm 0.00^{\mathrm{a}}$ & $0.00 \pm 0.00^{\mathrm{a}}$ & $0.00 \pm 0.00^{\mathrm{a}}$ \\
\hline Cinnamon oil & $13.83 \pm 2.32^{\mathrm{c}}$ & $15.37 \pm 2.58^{\mathrm{c}}$ & $16.00 \pm 1.79^{\mathrm{d}}$ & $17.78 \pm 1.99^{\mathrm{d}}$ \\
\hline Clove oil & $9.33 \pm 1.21^{\mathrm{b}}$ & $10.37 \pm 1.34^{b}$ & $9.33 \pm 0.52^{\mathrm{c}}$ & $10.37 \pm 0.57^{\mathrm{c}}$ \\
\hline Garlic oil & $0.09 \pm 0.00^{\mathrm{a}}$ & $0.01 \pm 0.00^{\mathrm{a}}$ & $0.09 \pm 0.00^{\mathrm{a}}$ & $0.01 \pm 0.00^{\mathrm{a}}$ \\
\hline Thyme oil & $0.09 \pm 0.00^{\mathrm{a}}$ & $0.01 \pm 0.00^{\mathrm{a}}$ & $2.00 \pm 1.26^{\mathrm{b}}$ & $2.22 \pm 1.40^{\mathrm{b}}$ \\
\hline
\end{tabular}

Mean values with different letters are significantly different at 5\% level according to Duncan's multiple range test.

Combinations activities of antifungal drugs and essential oils against fungal growth

Combination between antifungal drugs and essential oils had been tested and the interaction between them (antagonism, synergism or indifference) was determined by the functional inhibitory concentration index (FICI) as mentioned in materials and methods. The data represented in Fig. 2 - 5 revealed indifference interaction between the single treatments and combination treatments against both fungi tested in case of cinnamon and clove containing mixtures. However, garlic and thyme oils interacted synergistically with antifungals increasing their efficacy in almost all mixtures. Antagonistic interaction was recorded in mixtures of garlic oil + fluconazole and thyme + fluconazole where they decreasing their efficacy. Generally the highest control of both fungal species was showed by single treatment of clotrimazole. 
D.M.I. ALI et al.

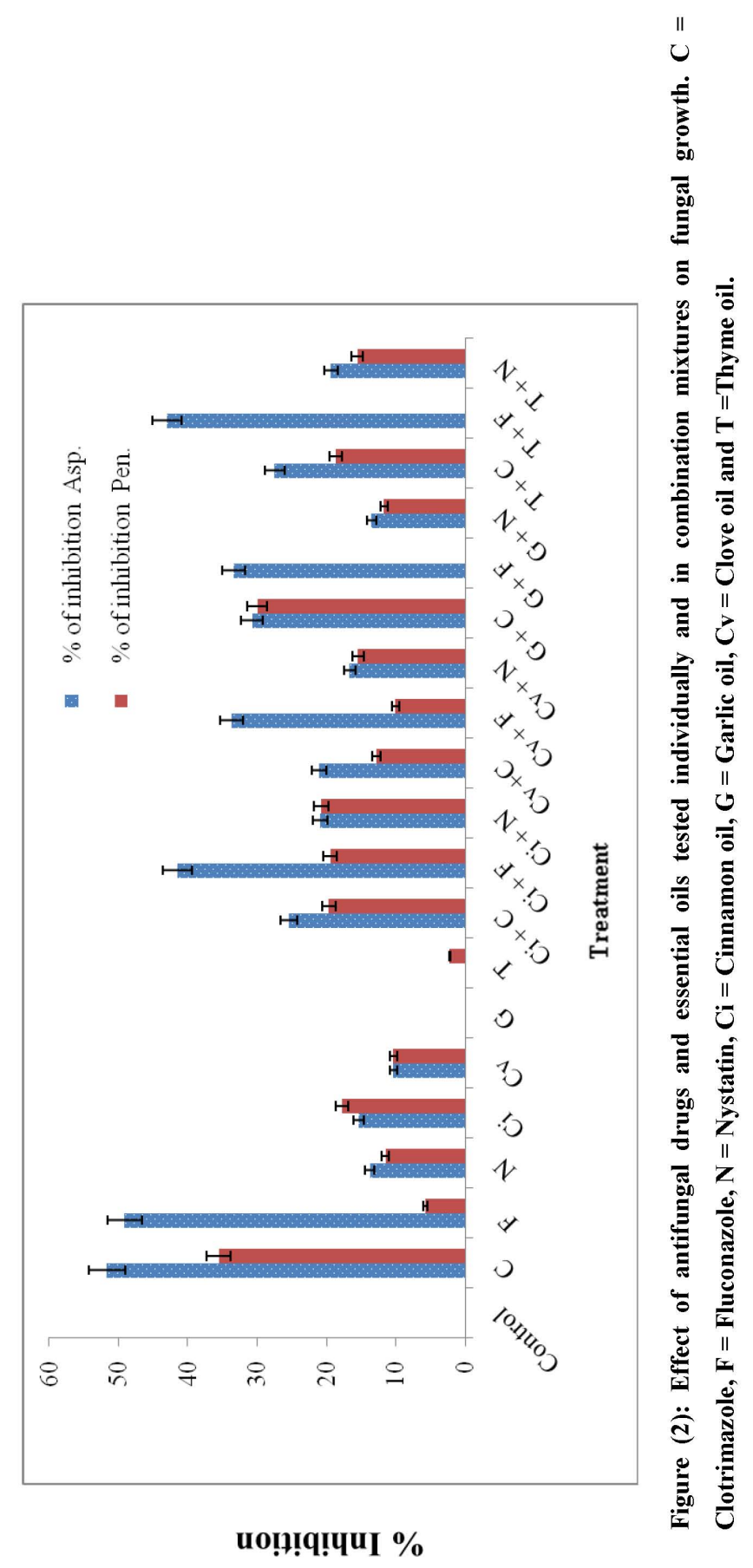

Egypt. J. Bot., 54, No.2 (2014) 
CONTROL OF FUNGAL PAPER DETERIORATION BY ANTIFUNGAL ... 229
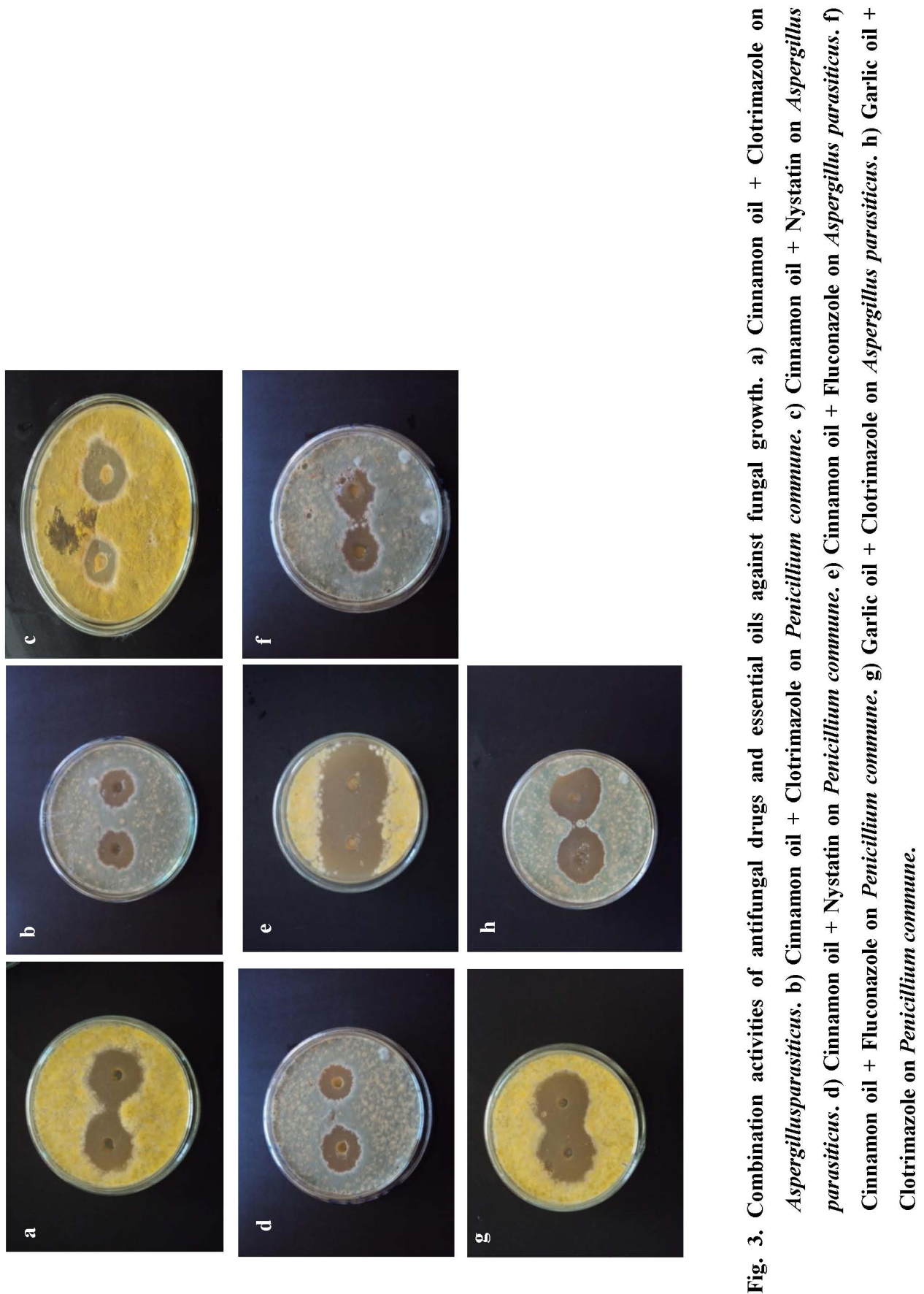

Egypt. J. Bot., 54, No.2 (2014) 

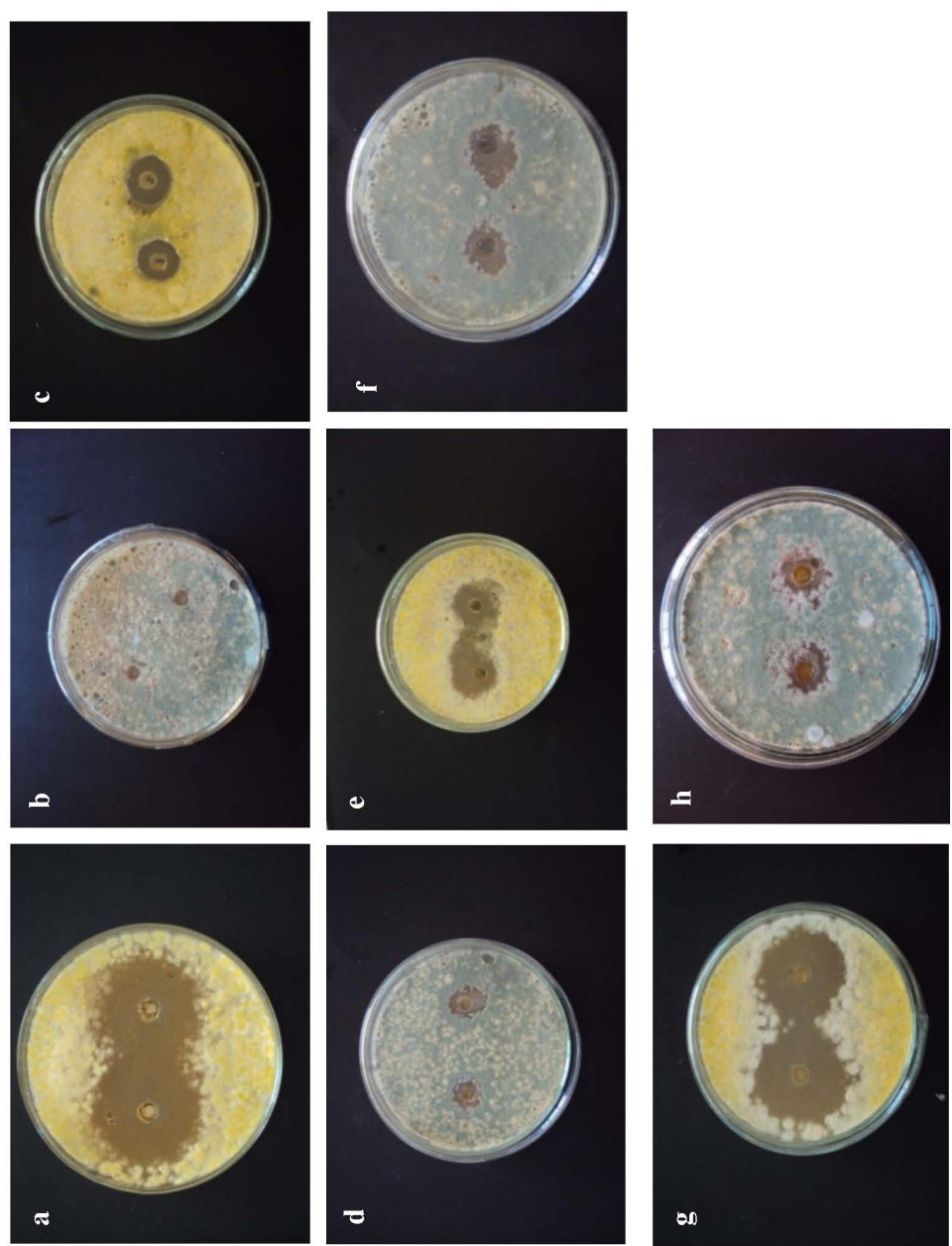

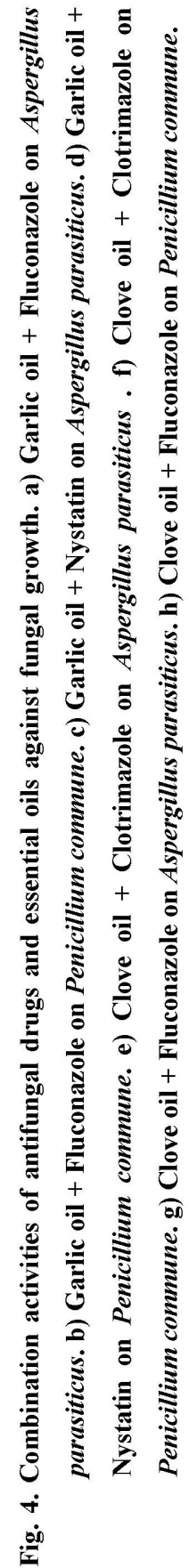

Egypt. J. Bot., 54, No.2 (2014) 
CONTROL OF FUNGAL PAPER DETERIORATION BY ANTIFUNGAL ... 231
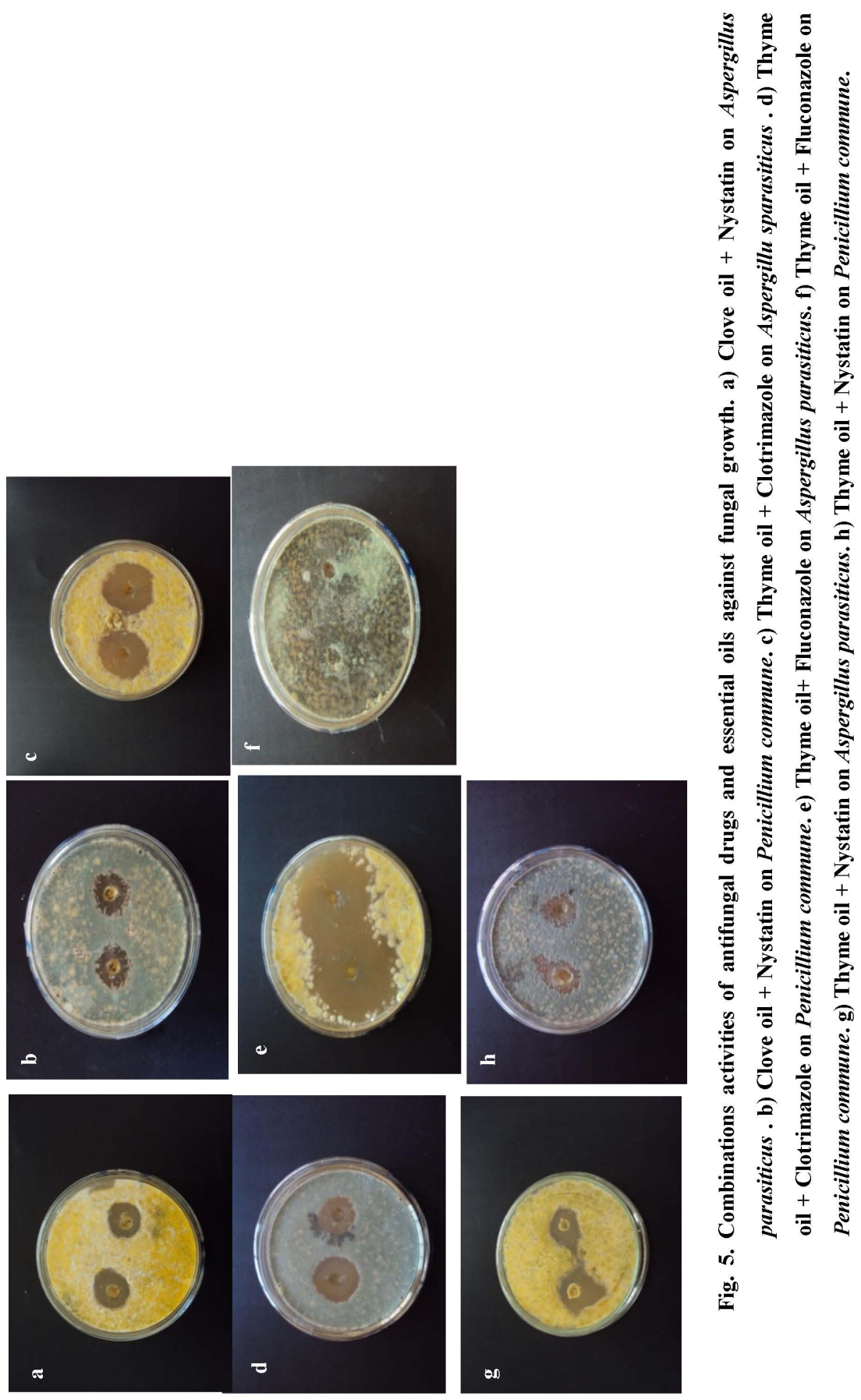

Egypt. J. Bot., 54, No.2 (2014) 
It could be concluded that the action of single treatment with either antifungal drugs or essential oils on paper deteriorating fungi are fungistatic rather than fungicidal. Combination of both increase efficaciesin some mixtures but the action is still fungistatic. Their use may be beneficial as a complement to treat environment in libraries to prevent new combination in stored books and other archive materials.

The awareness of microbial deterioration of library materials came only after investigating the Ludwig Pasteur and Robert Koch. While cedar oils and lemon flavor extracts were used in ancient libraries to protect papyrus from the insect attack.

Interestingly, Rakotoniraing and Lavedrine (2005) investigated the inhibitory action of vapour phase of essential oils of armoise, clove, boldo, eucalyptus, ravensare, lavender, tea tree, thuya, wormseed and their main components against mould species commonly found on library and archive materials. Among oils, wormseed oil showed the strongest antifungal activity. Among the chemical components linalool was the most efficient. At low concentration linalool exhibited higher activity than wormseed oil. Among fungi that resist all treatments Penicillium variotii and Aspergillus niger. Linalool vapour did not affect the brightness of papers tested or the degree of cellulose polymerization, but it reduces the $\mathrm{pH}$ of the paper which makes it susceptible to fungal degradation.

However, many factors affect the constituents of essential oils. Depending on the methods of extraction, ecological factors and biological parameters, the same species of plant can give rise to essential oils with different composition and different types of action (Pellecuer et al., 1976; Arras and Grella, 1992; McGimpey et al., 1994 and Echeverrigaray et al., 2003).

\section{Effect of gamma radiation on fungal growth}

The effect of different doses of gamma radiation on the fungal growth revealed that $\gamma$-irradiation proved to be effective treatment to paper deteriorating fungi at relatively low doses. Data in Table 4 indicated that the survival cfu / plate of the two tested fungal species decreased linearly by increasing the irradiation doses. A. parasiticus was more tolerant to some extent to $\gamma$ irradiation than $P$. commune where complete inhibitions were recorded in exposure to1.0KGy, and $0.8 \mathrm{KGy}$, respectively.

TABLE 4. Effect of different doses of gamma radiation on the fungal colony forming units after 5 days incubation.

\begin{tabular}{|c|c|c|c|c|c|c|}
\hline \multirow{3}{*}{$\begin{array}{c}\text { Dose } \\
\text { (KGy) }\end{array}$} & \multicolumn{3}{|c|}{ Aspergillus parasiticus } & \multicolumn{3}{|c|}{ Penicillium commune } \\
\hline & \multicolumn{3}{|c|}{ cfu / plate } & \multicolumn{3}{|c|}{ cfu / plate } \\
\hline & (Mean & \pm & SD) & (Mean & \pm & SD) \\
\hline 0.00 & 196.00 & \pm & $11.11^{\mathrm{d}}$ & 276.89 & \pm & $18.12^{\mathrm{e}}$ \\
\hline 0.20 & 131.30 & \pm & $8.21^{\mathrm{c}}$ & 152.30 & \pm & $9.11^{\mathrm{d}}$ \\
\hline 0.40 & 49.33 & \pm & $2.52^{b}$ & 77.33 & \pm & $2.11^{\mathrm{c}}$ \\
\hline 0.60 & 9.33 & \pm & $0.91^{\mathrm{a}}$ & 27.33 & \pm & $1.12^{\mathrm{b}}$ \\
\hline 0.80 & 1.00 & \pm & $0.00^{\mathrm{a}}$ & 0.00 & \pm & $0.00^{\mathrm{a}}$ \\
\hline 1.00 & 0.00 & \pm & $0.00^{\mathrm{a}}$ & 0.00 & \pm & $0.00^{\mathrm{a}}$ \\
\hline 2.00 & 0.00 & \pm & $0.00^{\mathrm{a}}$ & 0.00 & \pm & $0.00^{\mathrm{a}}$ \\
\hline
\end{tabular}

Mean values with different letters are significantly different at 5\% level according to Duncan's multiple range test. cfu: colony forming unit.

Egypt. J. Bot., 54, No.2 (2014) 
The results in (Table 5) showed that the mycelial dry biomasses decreased by increasing the irradiation doses up to $1 \mathrm{KGy}$ in the two tested fungi after incubation for ten days. There was no growth at $2 \mathrm{KGy}$. In case of A. parasiticus dry biomasses, there was no significant difference between the doses $0.2,0.4$ and $0.6 \mathrm{KGy}$. At the doses 0.8 and $1.0 \mathrm{KGy}$, significant decrease in dry biomass of $A$. parasiticus was obtained. The data also revealed a remarkable reduction in the dry biomasses of P.commune by increasing the irradiation doses starting from $0.2 \mathrm{KGy}$. The dose $2.0 \mathrm{KGy}$ was lethal to the growth and biomasses gain in both fungal species.

TABLE 5. Effect of different doses of gamma radiation on the fungal mycelial dry biomasses after 10 days incubation.

\begin{tabular}{|c|c|c|c|c|c|c|}
\hline \multirow{3}{*}{$\begin{array}{c}\text { Dose } \\
\text { (KGy) }\end{array}$} & \multicolumn{3}{|c|}{ A. parasiticus } & \multicolumn{3}{|c|}{ P. commune } \\
\hline & \multicolumn{3}{|c|}{ DB (mg/flask) } & \multicolumn{3}{|c|}{ DB (mg/flask) } \\
\hline & (Mean & \pm & SD) & (Mean & \pm & SD) \\
\hline 0.0 & 132.0 & \pm & $10.1^{\mathrm{b}}$ & 230.0 & \pm & $11.2^{\mathrm{c}}$ \\
\hline 0.2 & 125.0 & \pm & $11.2^{\mathrm{ab}}$ & 140.0 & \pm & $29.3^{b}$ \\
\hline 0.4 & 122.0 & \pm & $12.1^{\mathrm{ab}}$ & 64.0 & \pm & $11.4^{\mathrm{b}}$ \\
\hline 0.6 & 108.0 & \pm & $11.4^{\mathrm{ab}}$ & 63.0 & \pm & $9.1^{\mathrm{b}}$ \\
\hline 0.8 & 64.0 & \pm & $7.3^{\mathrm{b}}$ & 62.0 & \pm & $8.2^{\mathrm{b}}$ \\
\hline 1.0 & 54.0 & \pm & $5.5^{\mathrm{b}}$ & 54.0 & \pm & $6.1^{\mathrm{b}}$ \\
\hline 2.0 & 0.0 & \pm & $0.0^{\mathrm{a}}$ & 0.0 & \pm & $0.0^{\mathrm{a}}$ \\
\hline
\end{tabular}

Mean values with different letters are significantly different at $5 \%$ level according to Duncan's multiple range test.

DB: Dry Biomass

Determination of decimal reduction dose ( $D_{10}$-value $)$

The $\mathrm{D}_{10}$-value was determined by calculating the negative reciprocal of the slope by linear regression after plotting the survival data versus irradiation doses (Choi et al., 2012). The $\mathrm{D}_{10}$-value is defined as the dose of ionizing radiation required to reduce a given microbial population by $90 \%$ or by one logarithmic cycle.

The data in Table 6 indicated that the value of $\mathrm{D}_{10}(0.46)$ which reduced 90 of the growth of $A$. parasiticus was lower than that of $P$. commune $(0.60)$. This indicating the higher sensitivity of $A$. parasiticus to $\gamma$-irradiation than $P$. commune. 


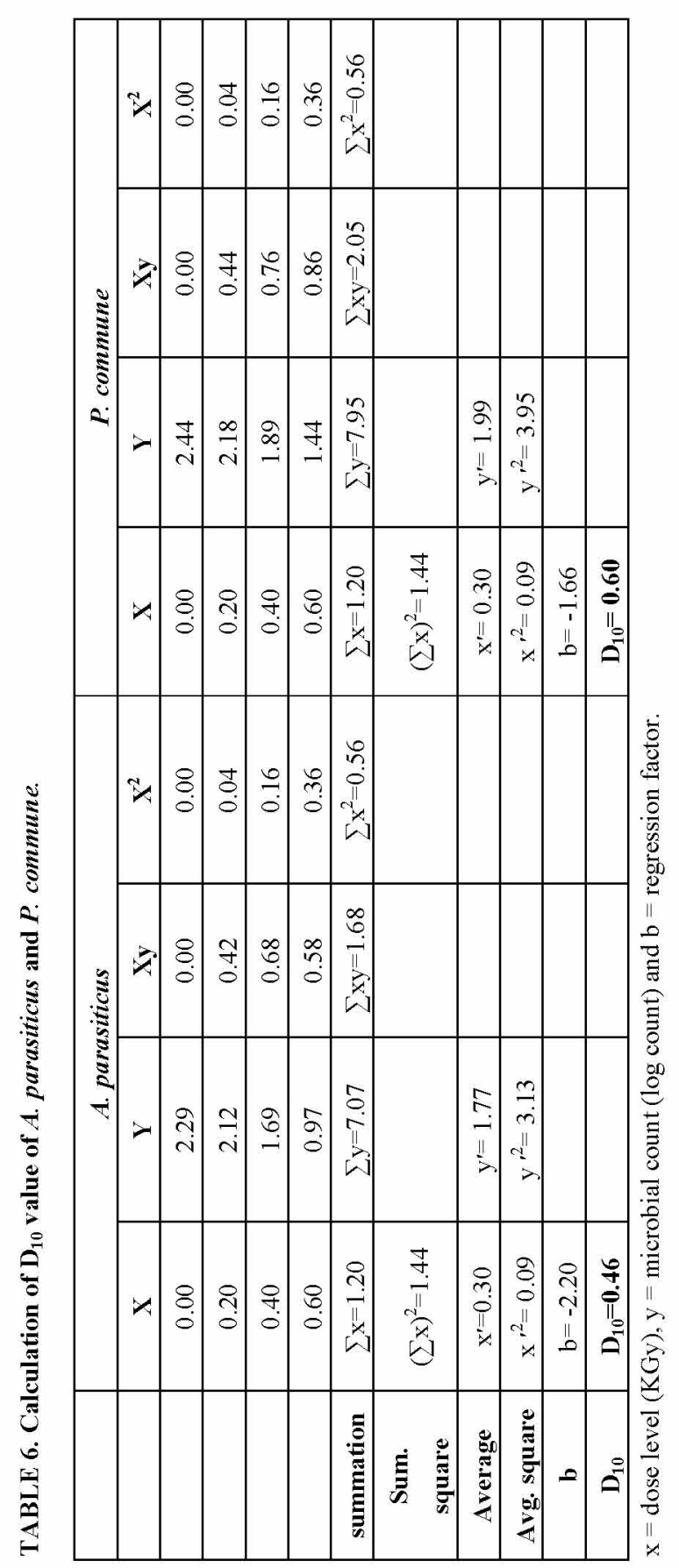

Egypt. J. Bot., 54, No.2 (2014) 
From the growth parameters data in Fig. 6, it was found that the two fungi responded differently against $\gamma$-irradiation. A. parasiticus was more tolerant than $P$. commune in its biomasses, while they were equal in $\gamma$-irradiation tolerance in the cfu / plate. The $\mathrm{D}_{10}$ determination revealed more tolerance of $P$. commune than A. parasiticus.

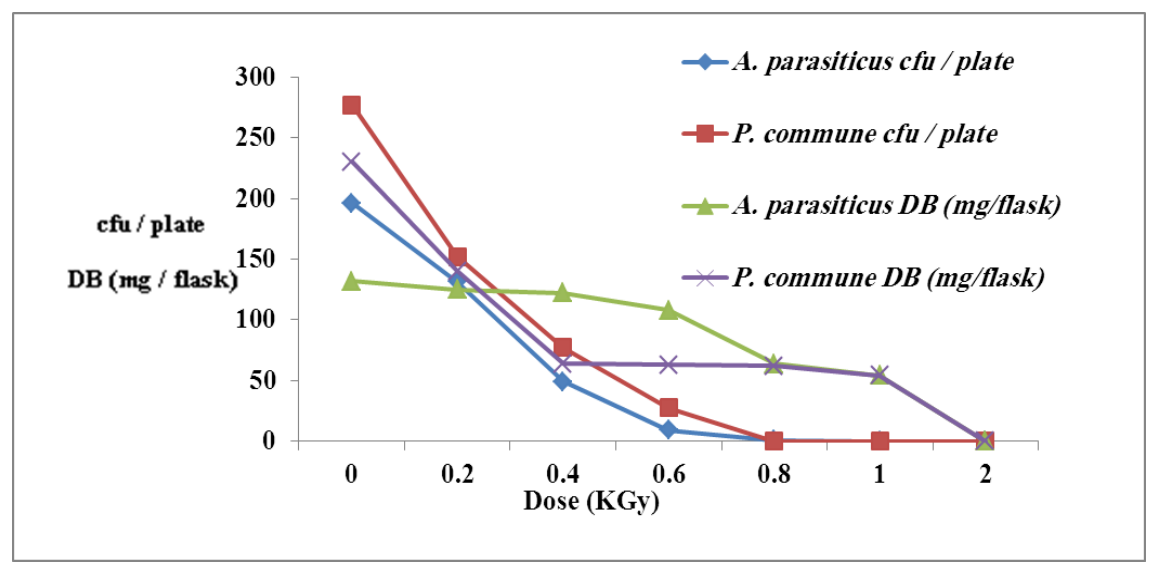

Fig. 6. Effect of gamma irradiation on fungal growth parameters.

-DB: dry biomass.

Gamma- irradiation is the most effective physical method for killing fungi and their spores. Many authors report that the dose ranged from 10 to $20 \mathrm{KGy}$ is needed for complete inhibition of fungal growth (Nitterus, 2000). However, such high doses of $\gamma$-irradiation significantly affect the chemical composition of cellulose fibers and thus the application dose has to be thoroughly considered. In similar studies lower doses of $\gamma$-irradiation were also reported by D'Almeida et al. (2009) who found that $\gamma$ - doses from 3-15 KGy at dose rate of $0.817 \mathrm{GY} / \mathrm{S}$ is successfully applied to books decontaminated by microorganisms under safety conditions. They recommended thinking about lowest radiation dose as possible and also verifying the dose rate for the process. Mangaudda (2004) proved that using $\gamma$-radiation is an efficient treatment (roughly $0.2-0.5 \mathrm{KGy}$ for fungi and 3$8 \mathrm{KGy}$ for insects). No significant harmful effect has occurred on the mechanical and physical properties of pure cellulose and paper or in printing ink.

Gamma -irradiation dose of $2.8 \mathrm{~Gy} / \mathrm{h}$ reduce the degree of cellulose fiber polymerization that is because the irradiation was long enough to allow oxidative degradation (Adamo et al.,1998).

The handling of books after $\gamma$-irradiation may be done safely because $\gamma$-rays pass through materials without leaving any residue (Adamo et al., 1998, 2001). It also causes no change in the physic-chemical characters of papers (Gonzales, 2002) or in printing compounds (Rocchetti et al., 2002). Superizingly, Da Silva et al. (2006) isolated and identified several fungi from contaminated books in a Brazilian public 
library and from the environment. Those were Acremonium, Aspergillus, Cladosporium, Fusarium, Penicillium, Trichospora. They were treated with $\gamma$ irradiation doses ranging from 14.5 to $25 \mathrm{KGy}$. The minimum lethal dose was 16 KGy. After the treatment no living fungi were detected from the irradiated material even the books were maintained in favorable condition for new fungal growth.

Effect of different doses of gamma radiation on the fungal caseinolytic, cellulolytic and amylolytic activities

Under control condition, the data in Tables $7 \& 8$ revealed that the caseinolytic activities of $A$. parasiticus and $P$. commune were higher than cellulolytic activities while amylolytic activities were of minor values. Comparing the two fungal species, it was found that $A$. parasiticus produces higher extracellular caseinolytic, amylolytic and cellulolytic activities than $P$. commune. Under control condition, $\gamma$ irradiation significantly reduced the activities of the three assayed enzymes, in dose dependent manner, in both fungal species. The dose $2 \mathrm{KGy}$ completely inactivated the three enzymes activities in both fungal species.

These results are promising and demonstrate the effectiveness of $\gamma$ irradiation for recovery of severely damaged books and old documents leading to preservation of our cultural heritage and prevention of human diseases caused by molds in libraries and archives. The used lethal dose (2KGy) exerts no harmful effect on paper material.

Gamma irradiation causes direct damage to cell DNA through ionization inducing mutation and death of the cells. It also exerts indirect effect through radiolysis of cellular water and formation of active oxygen species, free radicals and peroxides causing single and double strand DNA breakage (McNamara et al., 2003).

Because of the tremendous diversity of exoenzymes produced by fungi, cellulases, gluconases, laccases, phenolases, keratinases, mono-oxyginases, proteases, lipases and many more; the preservation of libraries and museum books and documents is inevitably connected with prevention of moulds by inhibiting these or most of these enzymes (Sterflinger, 2010).

Borrego et al. (2010) evaluated the microbial prevalence inside library (in Cuba) and museum archive(in Argentina)and reported that various fungal species produce cellulases, proteases and amylases and could degrade cellulose, proteins, starch and also excrete acids and pigments. 
CONTROL OF FUNGAL PAPER DETERIORATION BY ANTIFUNGAL ... 237

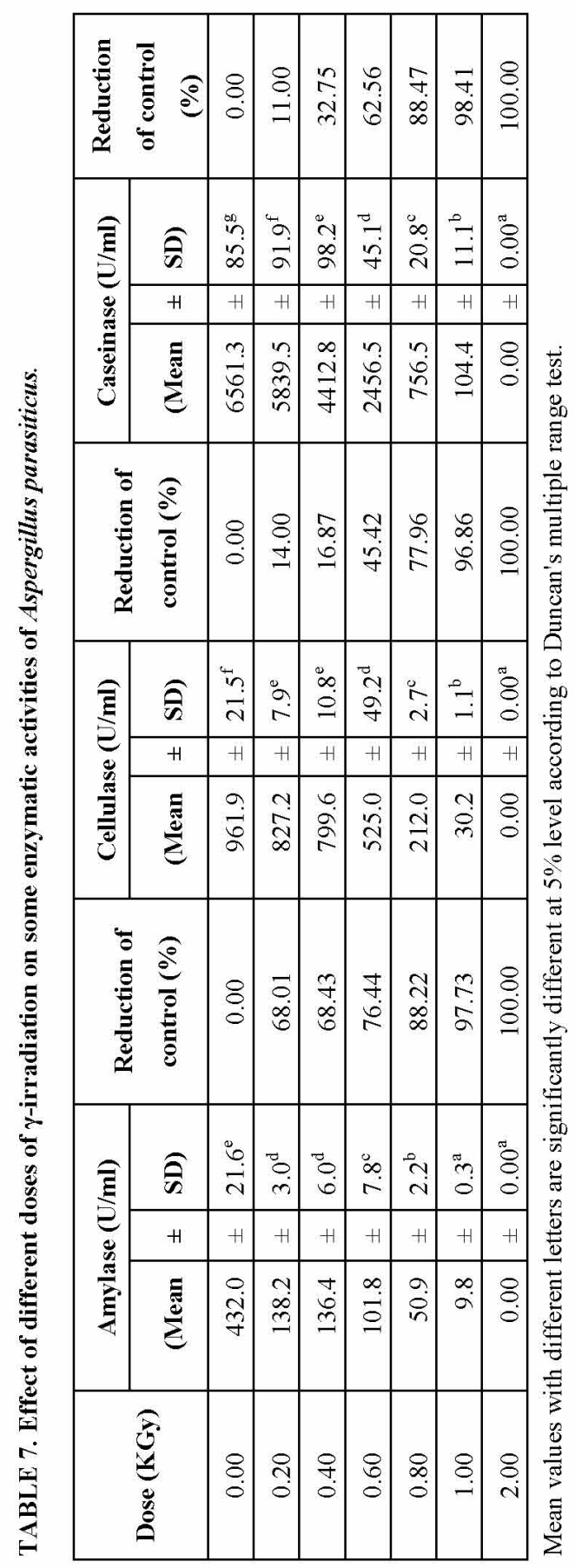

Egypt. J. Bot., 54, No.2 (2014) 


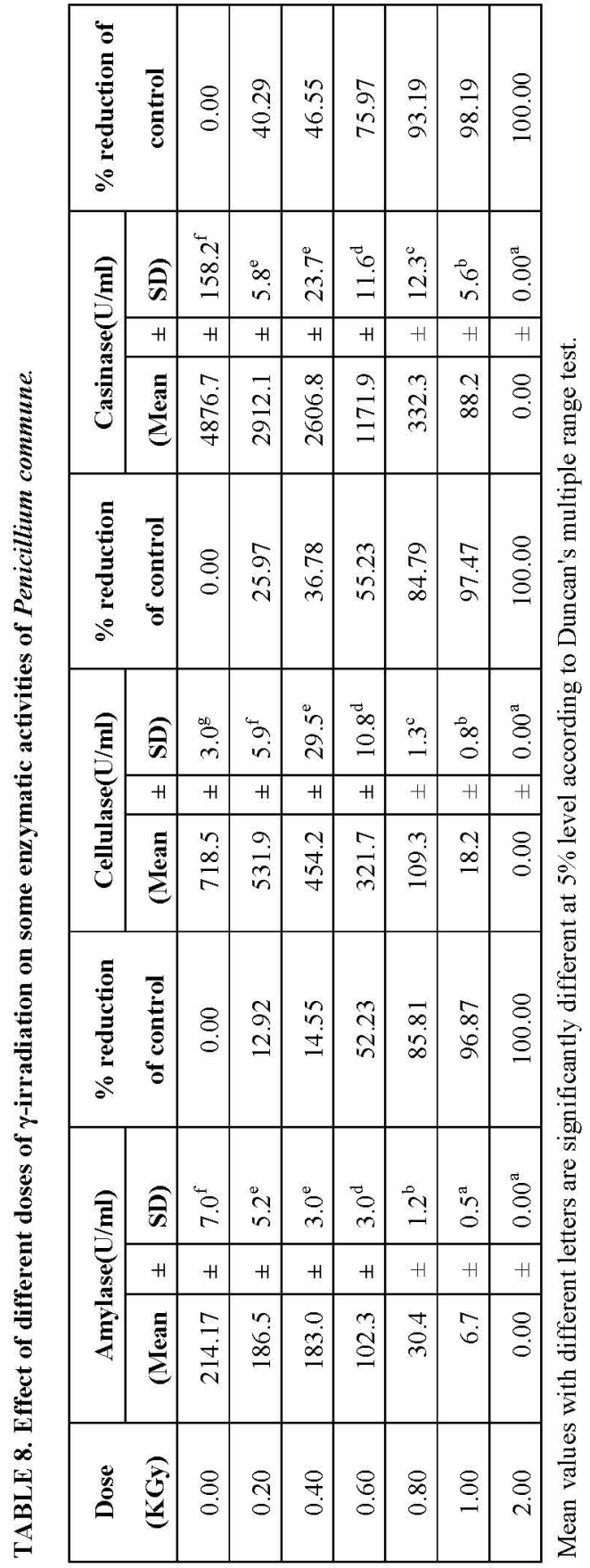

Egypt. J. Bot., 54, No.2 (2014) 
Guiamet et al. (2011) found that most fungi isolated from biodeteriorated photos and maps stored at Historical Archive of Museum La Plata, Argentina, degraded cellulose and produce extracellular cellulases, pigments and acids. Talaromyces helices (Penicillium teleomorph) has been reported from documents surfaces. It has cellulolytic activity (Moloney et al., 2004; Chacon \& Waliszewski, 2005) so its presence involves a high risk for document conservation. Cellulolytic fungi can destroy paper materials in short time (Adamo et al., 2003) hence it uses cellulose as carbon source.

Fungi degrade materials and thus affect objects substantially by enzymatic degradation of paper objects. Fungi penetrate cracks and migrate underneath upper layer and causes detachment. In paper conservation, considerable damage can be caused by cellulases and lipases (Bech-Andersen and Elborne, 2004).

\section{Control of paper deteriorating fungi by laser radiation}

The data in Fig. 7 revealed general reduction in the viable colonies (cfu) and dry biomass of both fungal species when exposed to laser beam as compared to control. Both parameters, however, showed persistence to extended exposure period to laser beam from 1 to 5 min with no significant decrease. After 10 and $15 \mathrm{~min}$, a reduction of $75 \%$ and $95 \%$ was recorded in the two growth parameters, respectively. Lethal laser effect had been detected after 20 min exposure in both fungal species.

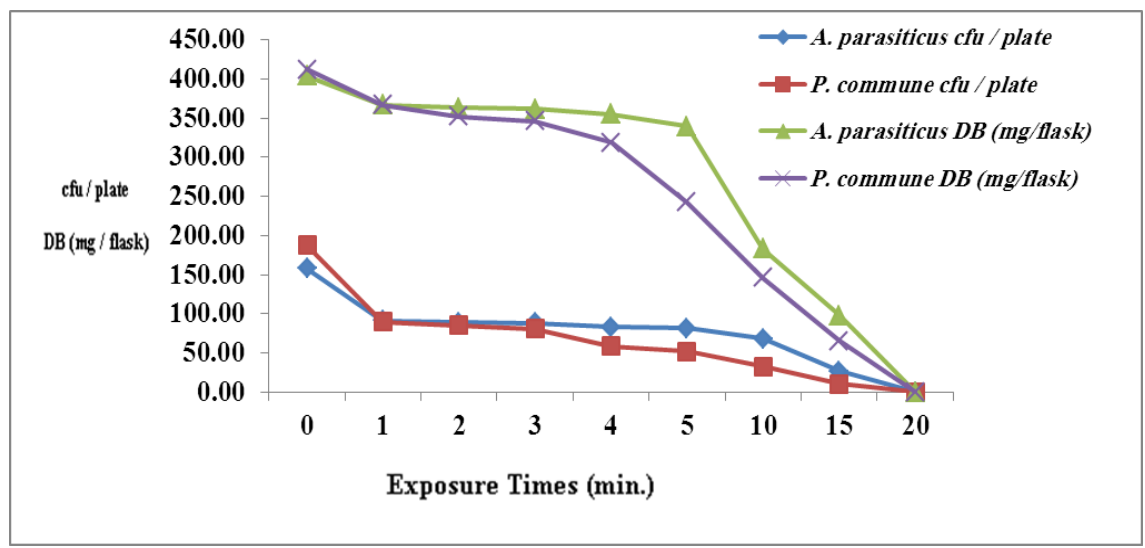

Fig. 7. Effect of laser irradiation on fungal growth parameters. -DB: dry biomass.

Kolar et al. (2003) found no immediate effects on paper irradiated with laser running at $532 \mathrm{~nm}$ or on solid cellulose. Also, Kolar et al. (2000a) used contactless cleaning of paper surfaces by application of short laser pulses to remove foreign material, such as dirt which serves as a culture medium for microorganisms. Laser at $532 \mathrm{~nm}$ and fluencies below $0.86 \mathrm{~J} / \mathrm{cm}^{2}$ showed no degradation of paper. 
It has been suggested that laser cleaning of ancient parchment manuscripts from the $15^{\text {th }}$ and $16^{\text {th }}$ century and printed paper from $19^{\text {th }}$ century to remove dirt and microorganisms was maintained by Kautek et al., 1998. This method avoids the toxic cleaning fluids and has potential to accelerate conservation work offering high quality results and save costs. Ochocinska et al. (2003) reported that the penetration depth as well as the dose of laser energy delivered can be controlled, and therefore the risk of possible damage to the treated old documents and works of arts can be markedly reduced during restoration and cleaning from microbial spores and dirts. The less destructive wavelength $(532 \mathrm{~nm})$ and energy fluencies $\left(<1 \mathrm{~J} / \mathrm{cm}^{2}\right)$ are recommended by (Kolar et al., 2000b).

It is worth mentioning that Speranza et al. (2012) controlled stone biodeterioration in heritage buildings by endolithic algae, fungi and the lichen Verrucaria nigrescence by using pulsed laser of $1064 \mathrm{~nm}$ from Nd:YAG laser. The fungal and algal cells were completely destroyed or presented a high plasmolysis degree resulting from heating microenvironment.

Finally, an advanced knowledge and thorough understanding of the materials from which the paper made together with identification and characterization of any original damage are fundamental prior to carry out any restoration work. Furthermore the precise identification of the microbial species which responsible for the damage is also an important require.

\section{References}

Abrusci, C., Martin-Gonzalez, A., Del Amo, A., Catalina, F., Collado, J. and Platas, G., (2005) Isolation and identification of bacteria and fungi from cinematographic films. International Biodeterioration\& Biodegradation , 56, 58-68.

Adamo, M., Brizzi, M., Magaudda, G., Martinelli, G., Plossi-Zappala, M., Rocchetti, F. and Savagnone, F. (2001) Gamma radiation treatment of paper in different environmental conditions. Restaurator, 22, 107-131.

Adamo, M., Giovannotti, M., Magaudda, G., Plossi-Zappala, M., Rocchetti, F. and Rossi, G. (1998) Effect of gamma rays on pure cellulose paper as a model for the study of a treatment of "biological recovery" of biodeteriorated books. Restaurator, 19, 41-59.

Adamo, M., Magaudda, G., Nisini, P.T. and Tronelli, G. (2003) Susceptibility of cellulose to attack by cellulolytic microfungi after gamma irradiation and ageing. Restaurator, 24, 145-151.

Adams, S., Kunz, B. and Weidenborner, M. (1996) Mycelial deformations of Cladosporium herbarum due to the application of eugenolorcarvacrol. Journal of Essential Oil Research , 8, 535-540.

Arras, G. and Grella, G.E. (1992) Wild thyme, Thymus capitatus, essential oil seasonal changes and antimycotic activity. Journal of Horticultural Science , 67, 197-202.

Egypt. J. Bot., 54, No.2 (2014) 
Bech-Andersen, J. and Elborne,S.A. (2004) The true dry rot fungus (Serpulalacrymans) from nature to houses. In: "European Research on Cultural Heritage State of the Art Studies". Dradacky, M. (Ed), 2, 445-448.

Beech, I.B. and Sunner, J. (2004) Biocorrosion: towards understanding interactions between biofilms and metals, Curr. Opin. Biotechnol, 15, 181-186.

Bishop, C.D. and Thornton, I.B. (1996) Evaluation of the antifungal activity of the essential oils of Monardacitriodora var. citriodora and Melaleucaalternifolia on post harvest pathogens. Journal of Essential Oil Research , 9, 77-82.

Borrego, S., Guiamet, P., Gómez de Saravia, S., Battistoni, P., Garcia, M., Lavin, P. and Perdomo, I. (2010) The quality of air at archives and the biodeterioration of photographs, International Biodeterioration \& Biodegradation, 64, 139-145.

Burns, T., Wilson, M. and Pearson, G. (1993) Sensitisation of cariogenic bacteria to killing by light from a helium- neon laser. Journal of Medical Microbiology. 38, 401-405.

Cappitelli, F. and Sorlini, C. (2005) From papyrus to compact disc: the microbial deterioration of documentary heritage. Critical Reviews in Microbiology, 31,1-10.

Chacon, S.L.O. and Waliszewski, K.N. (2005) Preparativos de celulasascomerciales y aplicaciones en procesosextractivos, Universidad y Ciencia , 21. 113-122.

Chingduang, S., Siriacha, P. and Saito, M. (1995) Effect of some medicinal plants and spices on growth of fungi. Proceeding of the Third International Conference on Biodeterioration of Cultural property. The Conservation Science Division, The Fine Arts Department, Bangkok, pp. 219-225.

Choi, J., Chung, Y.J., Kang, D.I., Lee, K.S. and Lee, J. (2012) Effect of radiation on disinfection and mechanical properties of Korean traditional paper, Hanji. Radiation Physics and Chemistry, 81,1051-1054

Clausen, C.A. (2000) Recognize, remove, and remediate mold and mildew. Proceedings of the Second Annual Conference on Durability and Disaster Mitigation in WoodFrame Housing, pp. 231-234.

Coughian, M.P., Touhy, M.G., Filho, X.F., Puls, J., Claeyssens, M., Vrsanska, M. and Hughes, M.M. (1993) Enzymological aspects of microbial emphasis on fungal system. In : "Hemicellulose and Hemicellulases", M.P. Coughlan and G.P. Hazlewood, (Ed.), pp. 53-85, Portland Press, London.

D'Almeida, M.L.O., Barbosa, P.d.S.M., Boaratti, M.F.G. and Borrely, S.I. (2009) Radiation effects on the integrity of paper. Radiat. Phys. Chem, 78 (7-8), 489-492.

Da Silva, M., Moraes, A.M.L., Nishikawa, M.M., Gattic, M.J.A., Vallim, de Alencard, M.A., Brandao, L.E. and Nobrega, A. (2006) Inactivation of fungi from deteriorated paper materials by radiation. Int. Biodeteriorat. Biodegradat, 57 (3), 163-167.

Dhawan, S. (1995) Essential oil for prevention of mould growth on palm leaf manuscripts. Proceeding of the Third International Conference on Biodeterioration of 
Cultural Property. The Conservation Science Division, The Fine Arts Department, Bangkok, pp. 272-282.

Echeverrigaray, S., Fracaro, F., Atti dos Santos, A.C., Paroul, N., Wasum, R. and AttiSerafini, L. (2003) Essential oil composition of south Brazilian populations of Cunilagalioides and its relation with the geographic distribution. Biochemical Systematics and Ecology, 31, 467-475.

Fabbri, A.A., Ricelli, A., Brasini, S. and Fanelli, C. (1997) Effect of different antifungals on the control of paper biodeterioration caused by fungi. International Biodeterioration\& Biodegradation, 39, 61-65.

Gatenby, S. and Townley, P. (2003) Preliminary research into the use of the essential oil of Melaceucaalternifolia (tea tree oil) in museum conservation. AICCM Bulletin, 28, $67-70$.

Ghose, T.K. (1987) Measurement of cellulase activities. Pure and Applied Chemistry, 59, 257-268.

Gilbert, P. and Brown, M.R.W. (1995) Some perspectives on preservation and disinfection in the present day. International Biodeterioration \& Biodegradation 36, 219-226.

Gonzalez, M.E., Calvo, A.M. and Kairiyama, E. (2002) Gamma radiation for preservation of biologically damaged paper. Radiation Physics and Chemistry, 63, 263-265.

Guiamet, P., Borrego, S., Lavin, P., Perdomo, I. and Gómez de Saravia, S. (2011) Biofouling and biodeterioration in materials stored at the HistoricaArchive of the Museum of La Plata, Argentine and at the National Archive of the Republic of Cuba. Colloids and Surfaces B: Biointerfaces.

Guynot, M.E., Ramos, A.J., Seto, L., Purroy, P., Sanchis, V. and Martin, S. (2003) Antifungal activity of volatile compounds generated by essential oils against fungi commonly causing deterioration of bakery products. Journal of Applied Microbiology 94, 893-899.

Hanus, J. (1985) Gamma radiation for use in archives and libraries. Abbey Newsletter, 9, 34-36.

Harvey, S.C. (1985) Antiseptics and disinfectans; fungicides; ectoparasiticides. In : "The Pharmacological Basis of Therapeutics", A. Goodman, Gilman, L.S. Goodman, T.W. Rall and F. Murad. (Ed.) MacMillan Publishing Company, New York, pp. 959-979.

Hitokoto, H., Morozumi, S., Wauke, T., Sakai, S. and Ueno, I. (1980) Inhibitory effect of spices on growth and toxin production by toxigenic fungi. Applied and Environmental Microbiology, 39, 818-822.

Hueck, H.J. (1965) The biodeterioration of materials as a part of hydrobiology, Mater. Organismen, 1, 5-34.

Egypt. J. Bot., 54, No.2 (2014) 
CONTROL OF FUNGAL PAPER DETERIORATION BY ANTIFUNGAL ... 243

Jones, D.L., Owen, A.G. and Farrar, J.F. (2002) Simple method to enable the high resolution determination of total free amino acids in soil solutions and soil extracts. Soil Biology and Biochemistry, 34 (12), 1893-1902.

Jorg, M., Wildfuhr, W., Langguth, H. and Teichert, E., (1992) Gammastrahlen zur Schimmelbekampfung bei Buchern: Versuche an der Universitats-bibliothekzu Leipzig. Restauro 98, 114-119

Kautek, W., Pentzien, S., Rudolph, P., Kruger, J. and Konig, E. (1998) Laser interaction with coated collagen and cellulose fibre composites: fundamentals of laser cleaning of ancient parchment manuscripts and paper, Applied Surface Science, 127129, 746-754.

Kolar, J., Strlic, M., Muller-Hess, D., Gruber, A., Troschke, K., Pentzien, S. and Kautek, W. (2003) Laser cleaning of paper using Nd:YAG laser running at $532 \mathrm{~nm}$. Journal of Cultural Heritage , 4, 185s-187s.

Kolar, J., Strlic, M., Muller-Hess, D., Gruber, A., Troschke, K., Pentzien, S. and Kautek, W. (2000a) Near-UV and visible pulsed laser interaction with paper. Journal of Cultural Heritage $1,221_{\mathrm{S}}-224_{\mathrm{s}}$.

Kolar, J., Strlic, M., Pentzien, S. and Kautek, W. (2000b) Near-UV, visible and IR pulsed laser light interaction with cellulose, Applied Physics, A 71, 87-90.

Kowalik, R. (1980) Microbiodeterioration of library materials. Restaurator, 4, 99-114.

Magaudda, G. (2004) The recovery of biodeteriorated books and archive documents through gamma radiation: some considerations on the results achieved. Journal of Cultural Heritage, 5, 113-118.

Mahmoud, A.L.E. (1994) Antifungal action and antiaflatoxigenic properties of some essential oil constituents. Letters in Applied Microbiology, 19, 110-113.

Manevitch, Z., Lev, D., Hochberg, M., Palhan, M., Lewis, A. and Enk, C.D. (2010) Direct antifungal effect of femtosecond laser on Trichophyton rubrumonychomycosis. Photochemistry and photobiology, 86, 476-479.

McGimpey, J.A., Douglas, M.H., Van Klink, J.L., Beauregard, D.A. and Perry, N.B., (1994) Seasonal variation in essential oil yield and composition from naturalized Thymus vulgaris L. in New Zealand. Flavour and Fragrance Journal, 9, 347-352.

McNamara, N.P., Black, H.I.J., Beresford, N.A. and Parekh, N.R. (2003) Effects of acute gamma irradiation on chemical, physical and biological properties of soils. Applied Soil Ecology, 24, 117-132.

Merck, E. (1982) "Hand Book of Culture Media".

Mesquita, N., Portugal, A., Videira, S., Rodriguez-Echeverria, S., Bandeira A.M.L. and Santos, M.J.A. (2009) Fungal diversity in ancient documents. A case study on the archive of the University of Coimbra. International Biodeterioration \& Biodegradation, 63, 626-9. 
Moloney, A.P., Considine, P.J. and Coughlan, M.P. (2004) Cellulose hydrolysis by the cellulases produced by Talaromyces emersonii when grown on different inducing substrates, Biotechnol. Bioeng , 25, 1169-1173.

Montes-Belmont, R. and Carvajal, M. (1998) Control of Aspergillus flavus in maize with plant essential oils and their components. Journal of Food Protection 61, 616 -619.

Mukherjee, P.K., Sheehan, D.J., Hitch-cook, C.A. and Channoum, M.A. (2005) Combination treatment of invasive fungal infections. Clinical Microbial Review, pp 163- 194

Neves, E.R., Scha“fer, S., Phillips, A., Canejo, J. and Macedo, M.F. (2009) Antifungal effect of different methyl and propyl paraben mixtures on the treatment of paper biodeterioration. International Biodeterioration \& Biodegradation , 63, 267-272.

Nitte'rus, M. (2000) Fungi in archives and libraries, a literary survey. Restaurator, 21, 25-40.

Ochocinska, K., Kaminska, A. and Sliwinski, G. (2003) Experimental investigations of stained paper documents cleaned by the Nd:YAG laser pulses. Journal of Cultural Heritage , 4, $188_{\mathrm{S}}-193_{\mathrm{s}}$.

Parks, L.W. and Casey, W.M. (1996) Fungal sterols, In : "Lipids of Pathogenic Fungi". R. Prasad and M. Ghannoum (Ed.), CRC Press, Inc., Boca Raton, Fla. pp. 63-82.

Pattnaik, S., Subramanyam, V.R. and Kole, C. (1996) Antibacterial and antifungal activity of ten essential oils in vitro. Microbios 86, 237-246.

Pellecuer, J., Allegrini, J. and Simeon de Buochberg, M. (1976) Huilesessentielles bactericides et fongicides. Revue de l'Institut Pasteur deLyon, 9, 135-159.

Perumal, P. and Wheeler, M. (1997) Traditional practices for the control of insects in India. $V$ \& A Conservation Journal , 23, 8-9.

Pointing, S.B., Jones, E.B.G. and Jones, A.M. (1998) Decay prevention in water logged archaeological wood using gamma irradiation. International Biodeterioration \& Biodegradation, 42, 17-24.

Rakotonirainy, M., Fohrer, F. and Flieder, F. (1999) Research on fungicides for aerial disinfection by thermal fogging in libraries and archives. International Biodeterioration \& Biodegradation , 44, 133-139.

Rakotonirainy, M.S. and Lavedrine, B. (2005) Screening for antifungal activity of essential oils and related compounds to control the biocontamination in libraries and archives storage areas. International Biodeterioration \& Biodegradation, 55, 141-147

Reis-Menezes, A.A., Gambale, W., Giudice, M.C. and Shirakawa, M.A. (2011) Accelerated testing of mold growth on traditional and recycled book paper. International Biodeterioration \& Biodegradation , 65, 423-428

Rocchetti, F., Adamo, M. and Magaudda, G. (2002) Fastness of printing inks subjected to gamma-ray irradiation and accelerated ageing. Restaurator, 23, 15-26.

Egypt. J. Bot., 54, No.2 (2014) 
CONTROL OF FUNGAL PAPER DETERIORATION BY ANTIFUNGAL ... 245

Smijs, T.G.M. and Schuitmaker, H.J. (2003) Photodynamic inactivation of the dermatophyte Trichophyton rubrum. Photochemistry and Photobiology 5.

Speranza, M., Sanz, M., Oujja, M., de los Rios, A., Wierzchos, J., Pérez-Ortega, S., Castillejo, M. and Ascaso, C. (2012) Nd-YAG laser irradiation damages to Verrucarianigrescens. International Biodeterioration \& Biodegradation. pp 1-10

Sterflinger, K. (2010) Review Fungi: Their role in deterioration of cultural heritage. Fungal Biology Reviews 24, 47-55

Thompson, D.P. (1989) Fungitoxic activity of essential oil components on food storage fungi. Mycologia, 81, 151-153.

Tomazello, M.G.C. and Wiendl, F.M. (1995) The applicability of gamma radiation to the control of fungi in naturally contaminated paper. Restaurator, 16, 83-99.

Vanden Bossche, H. (1990) Importance and role of sterols in fungal membranes. In : "Biochemistry of Cell Walls and Membranes in Fungi". P.J. Kuhn, A.P.J. Trinci, M.J. Jung, M.W. Gosey and L.P. Copping , (Ed.), Springer-Verlag, Berlin, pp. 135-1 57.

Villalba, L.S., Mikan, J.F. and Sanchez, J. (2004) Actividades hidrolíticas y caracterización isoenzimática de poblaciones microbianas aisladas del patrimonio documentaldel Archivo General de Colombia, NOVA , 2, 50-58.

Vural, E., Winfield, H.L., Shingleton, A.W., Horn, T.D. and Shafirstein, G. (2007) The effects of laser irradiation onTrichophytonrubrum growth. Lasers in Medical Science, 23, 349-353.

Zyska, B. (1997) Fungi isolated from library materials: a review of the literature. International Biodeterioration \& Biodegradation , 40 (1), 43-51.

(Received $7 / 11 / 2013$;

accepted $25 / 11 / 2013$ ) 


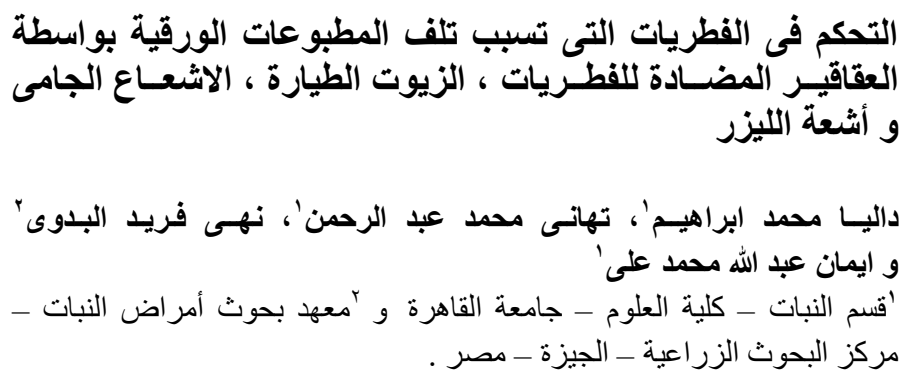

تهدف هذه الدراسة الى السبطرة على فطرتين مختارتين (الاسبيرجيللس

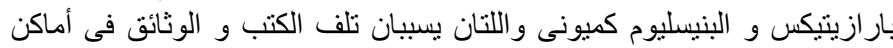

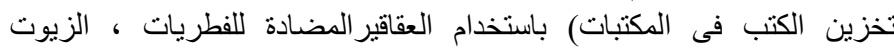

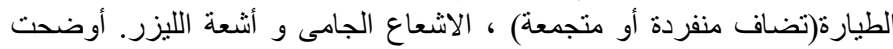

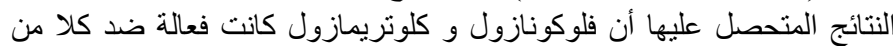

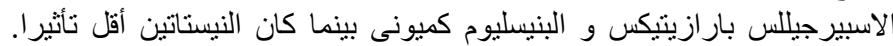

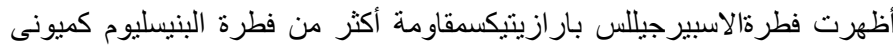

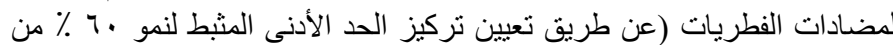

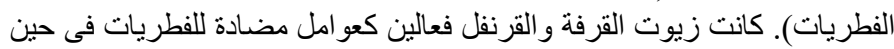

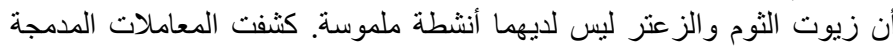

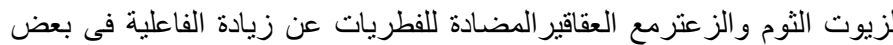

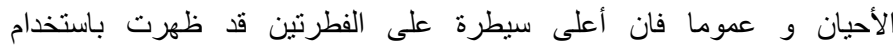

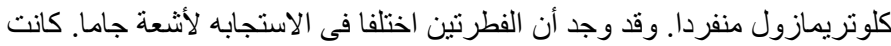

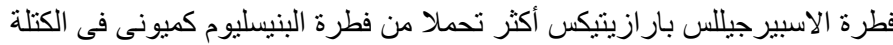

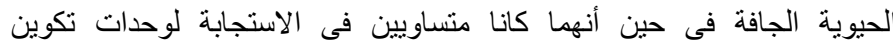

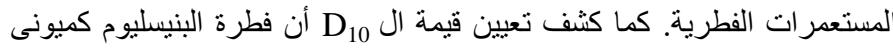

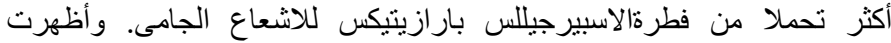

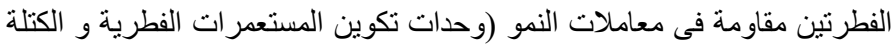

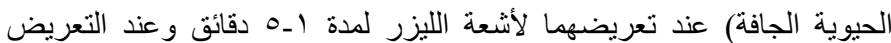

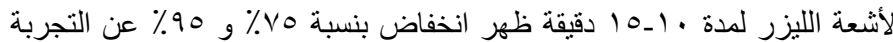

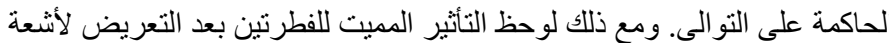
الليزر لمدة · ب دقيقة. 